Bangladesh J. Plant Taxon. 23(2): 247-253, 2016 (December)

(C) 2016 Bangladesh Association of Plant Taxonomists

\title{
PALYNOLOGICAL STUDIES ON SOME SPECIES OF ANABASIS L. (AMARANTHACEAE) FROM IRAN
}

\author{
M. Assadi, S.M.M. HAMDI ${ }^{1}$ AND F. FAJANI ${ }^{2}$ \\ Research Institute Rangelands and Forests, Tehran, Iran
}

Keywords: Amaranthaceae; Anabasis; Exine ornamentation; Palynology; Iran.

\begin{abstract}
The paper presents pollen micromorphology by scanning electron microscopy of seven Anabasis L. species namely, A. haussknechtii Bge., A. aphylla L., A. calcarea (Charif \& Allen) Bokhari \& Wendelbo, A. eugeniae Iljin, A. eriopoda (Shrernk) Volkens, A. annua Bge. and A. setifera Moq. from Iran. Pollen grains in all studied species are peripolyporate, spherical and are of two basic types based on pores diameter inner of holes. The study showed that the sculpturing of exine provides valuable characters in species delimitation, sometimes even for closely related ones. An artificial key based on pollen characters for seven species is provided.
\end{abstract}

\section{Introduction}

Amaranthaceae comprises of approximately 163 genera and 1825 species (Kadereit et al., 2003 and APG III, 2009). Anabasis belonging to the tribe Salsoleae s.l. is one of the largest tribes in Amaranthaceae, includes one-third of the genera currently recognized in the family (Ku"hn et al., 1993), distributed throughout arid, semiarid, saline, and hypersaline ecosystems of temperate and subtropical regions (Pyankov, et al., 2001; Kadereit et al., 2003 and Akhani et al., 2007). Anabasis is distributed in Iran by 10 species and 2 varieties (Freitag, 1997 and Assadi, 2001). Iran is one of the distribution centers for Anabasis (Akhani et al., 2007).

Tsukada (1967) studied amranth-chenopoid pollens by electron microscope and used pollen characters like pores, shape, size and conical tubercle as key characters. There is no study on the pollen micromorpholgy on Anabasis from Iran. The present study aims to investigate the pollen micromorpholgy of Anabasis, to evaluate its taxonomic value and to prepare an identification key for seven Anabasis species from Iran based on pollen micromorphological characters.

\section{Materials and Methods}

This study includes seven Anabasis species from Iran based on materials deposited in the National Herbarium of Iran, Research Institute of Forests and Rangelands (TARI) and Islamic Azad University Garmsar Herbarium (IAUGH) and also collected from different localities of Iran during 2013-2014 (Table 1). Pollen grains of 7 species of the genus Anabasis were studied by scanning electron microscope. Samples were obtained mostly from fresh collected herbarium specimens. The voucher and the pollen specimens, deposited in TARI Herbarium, are listed under table 1. For SEM, were used the protocol explained by Davies (1999) with some modifications. The specimens were mounted on $12.5 \mathrm{~mm}$ diameter stubs and attached with sticky tabs and then coated in a sputter coater with approximately $25 \mu \mathrm{m}$ of Gold- Paladium. Pollens were examined and photographed by a Philips scanning electron microscope model XL. Following quantitative

\footnotetext{
${ }^{1}$ Central Tehran Branch, Islamic Azad University, Tehran, Iran. Corresponding author. Email. m.hamdi@iauctb.ac.ir

${ }^{2}$ Garmsar Branch, Islamic Azad University, Garmsar, Iran.
} 
parameters were recorded: polar and equatorial pollen, P/E, pore diameters inner and outer, number of conical tubercle, pore high, distance between of centers of the adjacent pores and pores number. The terminology used for describing the pollens features followed in general by Moore et al. (1991) and Punt et al. (1994).

Table 1. Distribution of species of Anabasis L. studied.

\begin{tabular}{|c|c|c|c|c|c|}
\hline Species & Locality & Collector & $\begin{array}{l}\text { Altitude } \\
\text { (m) }\end{array}$ & $\begin{array}{l}\text { Herbarium } \\
\text { number }\end{array}$ & $\begin{array}{l}\text { Herbarium } \\
\text { name }\end{array}$ \\
\hline $\begin{array}{l}\text { Anabasis } \\
\text { setifera Moq. }\end{array}$ & Tehran-Eyvaneky, Roude Shour & Fajani & 780 & 5899 & IAUGH \\
\hline A. annua Bge & Kerman, 45 km to Mahan, & $\begin{array}{l}\text { Assadi \& } \\
\text { Amirabadi }\end{array}$ & 2300 & 66521 & TARI \\
\hline A. aphylla $\mathrm{L}$. & $\begin{array}{l}\text { Tehran, } 31 \mathrm{~km} \text { south of } \\
\text { Firouzkouh, Pirdeh }\end{array}$ & Fajani & 2200 & 5900 & IAUGH \\
\hline $\begin{array}{l}\text { A. haussknechtii } \\
\text { Bge. }\end{array}$ & $\begin{array}{l}\text { Semnan, } 10 \text { km, S.-E. Semnan, } \\
\text { near Aella village }\end{array}$ & Fajani & 1050 & 5901 & IAUGH \\
\hline A. eugeniae Iljin & $\begin{array}{l}\text { Azerbaijan, } 34 \text { km from } \\
\text { Alamdar toward Khodaafarin, } \\
\text { between Ahmadabad and } \\
\text { Siahroud }\end{array}$ & $\begin{array}{l}\text { Assadi and } \\
\text { Shahsavari }\end{array}$ & 700 & 65828 & TARI \\
\hline $\begin{array}{l}\text { A. eriopoda } \\
\text { (Shrenk) } \\
\text { Volkens }\end{array}$ & $\begin{array}{l}\text { Protected of Touran area, west- } \\
\text { nourth of Dochah, in road of } \\
\text { Chah Jaam }\end{array}$ & Feritag & 1150 & 14103 & TARI \\
\hline $\begin{array}{l}\text { A. calcarea } \\
\text { (Charif\&Aellen) } \\
\text { Bokhari and } \\
\text { Wendelbo }\end{array}$ & $\begin{array}{l}\text { Semnan, } 25 \mathrm{~km} \text { east-south of } \\
\text { Masnan in road of Taroud }\end{array}$ & $\begin{array}{l}\text { Wendelboo } \\
\text { and } \\
\text { Foroughi }\end{array}$ & 1120 & 18684 & TARI \\
\hline
\end{tabular}

\section{Results}

The main features of the investigated of pollen are summarized in Table 2. Our studies show that the sculpturing of exine provides valuable characters for separating the species, sometimes even for closely related ones, and delimitation of species. Pollen grains of all studied species are peripolyporate, spherical, having 32-83 conical tubercles on pore of pollen surface, polar length 12.4-26.10 $\mu \mathrm{m}$, equatorial length 9.83-25 $\mu \mathrm{m}$, number of pores 8-25 on pollen surface, 23-85 conical tubercle per $5 \mu \mathrm{m}$, distance between the center of adjacent pores $4.84-10 \mu \mathrm{m}$, pores diameter (outer) 3.5-10.2 $\mu \mathrm{m}$, pores diameter (inner) 2-6 $\mu \mathrm{m}$, pores height 0.1-0.35 $\mu \mathrm{m}$ and tectal of conical tubercle length $0.2-0.6 \mu \mathrm{m}$.

Following Punt et al. (1994) two basic types of pollen grains are distinguished based on holes pore diameters (inner), such as, Type A: pore diameter of holes (inner) on the exine is less than 3 $\mu \mathrm{m}^{2}$ and Type B: pore diameter of holes (inner) on the exine is more than $3 \mu \mathrm{m}$ (Table 2).

Type A includes A. eriopoda, A. haussknechtii, A. annua and A. aphylla; and Type B includes A.eugeniae, A. calcarea and A. setifera. On the basis of the exine sculpturing at proximal face, two main pollen types, as faveat tectum and faweat tectum are recognized (Table 2, Figs. 1\& 2). 


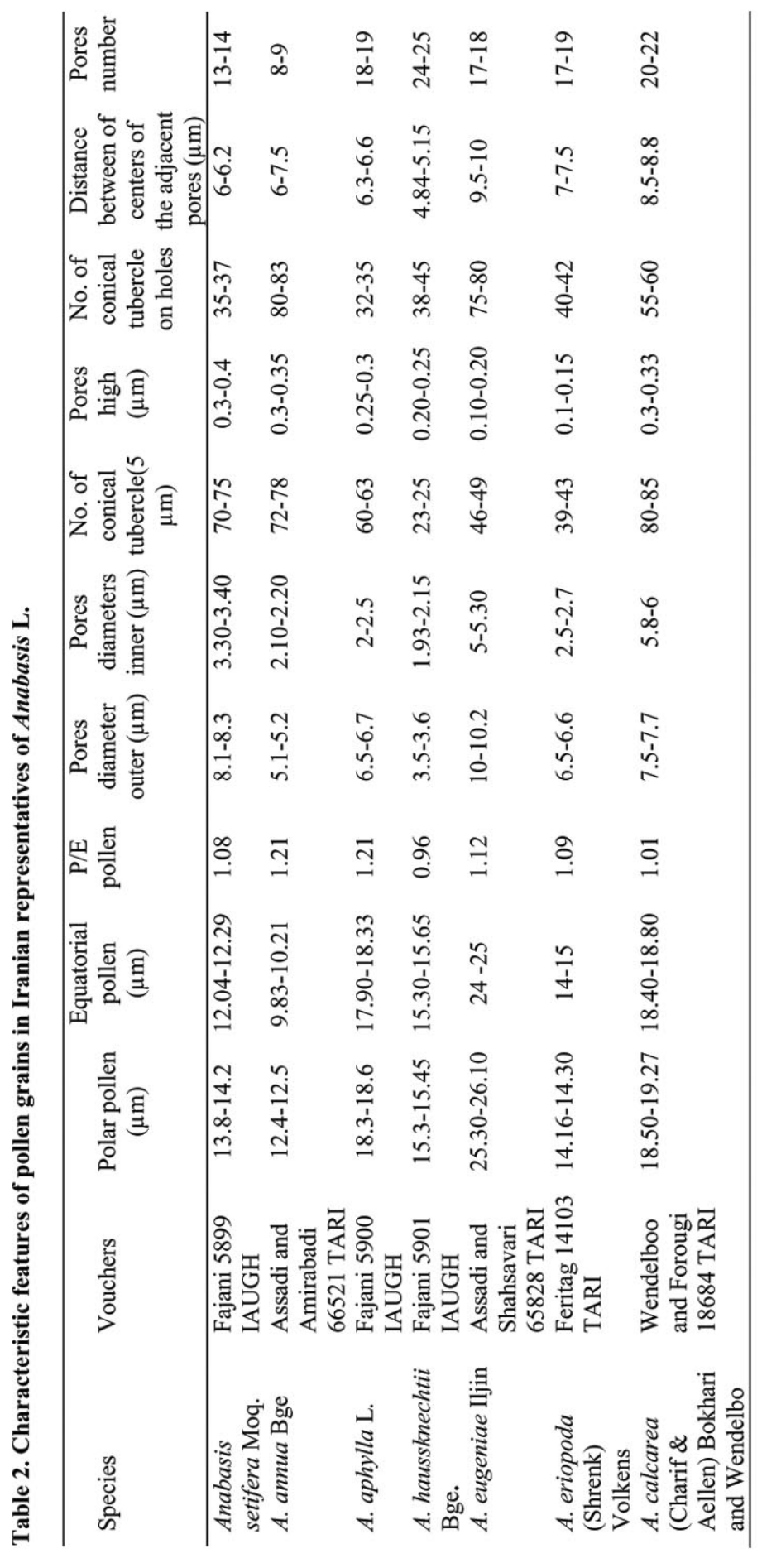



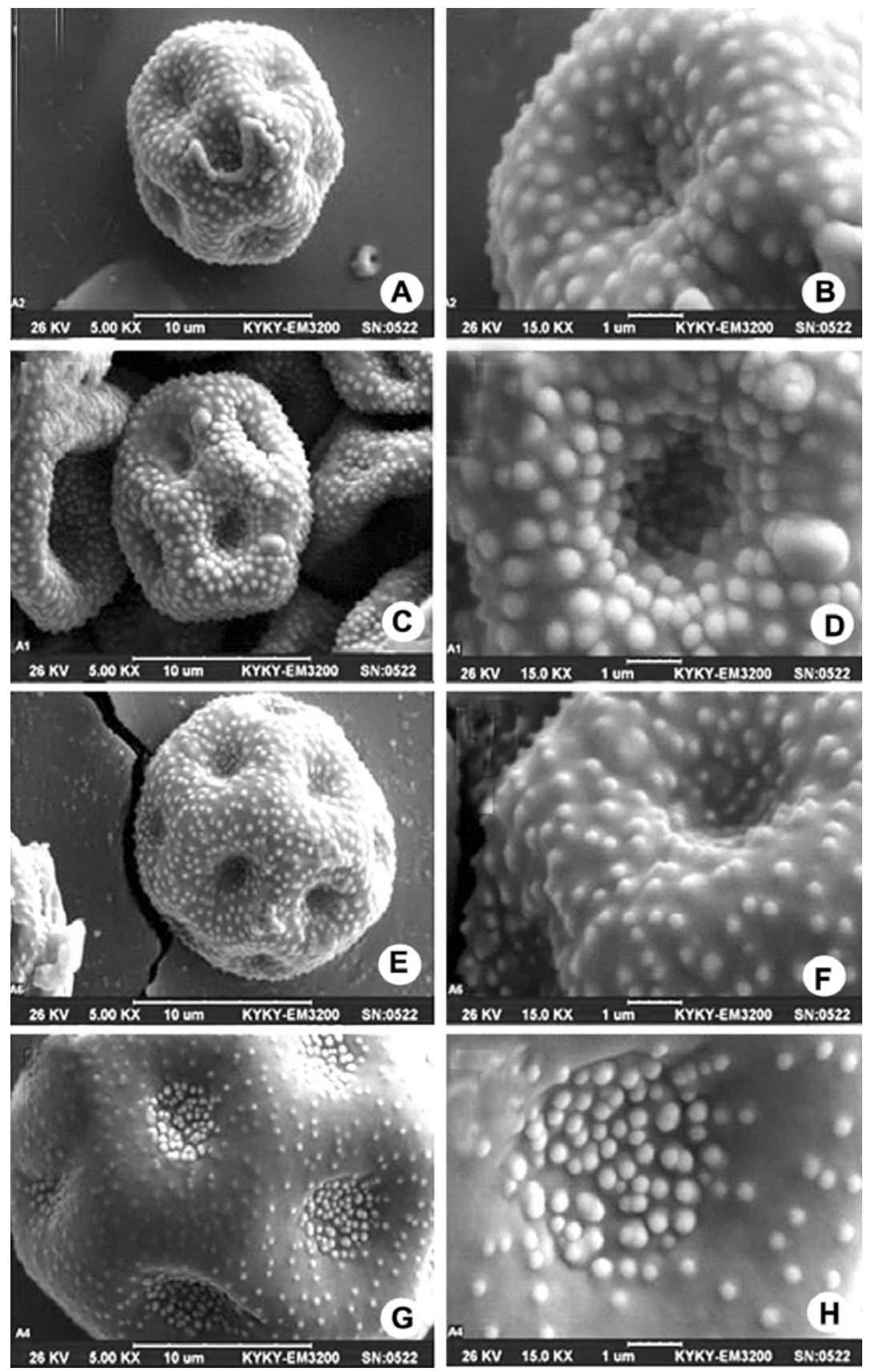

Fig. 1. Micrograph of pollen grains in Anabasis (Amaranthaceae). A-B, faveat tectum at the proximal face in A. setifera pollen with faveat ornamentation of exine. C-D, faweat tectum at the proximal face in $A$. annua pollen with faveat ornamentation of exine. E-F, faweat tectum at the proximal face in A. eriopoda pollen with faveat ornamentation of exine. $\mathrm{G}-\mathrm{H}$, faweat tectum at the proximal face in A.eugenia. pollen with faveat ornamentation of exine. Scale bars: A, C, E \& G= $10 \mu \mathrm{m} ; \mathrm{B}, \mathrm{D}, \mathrm{F}, \mathrm{H}$ $=1 \mu \mathrm{m}$. 

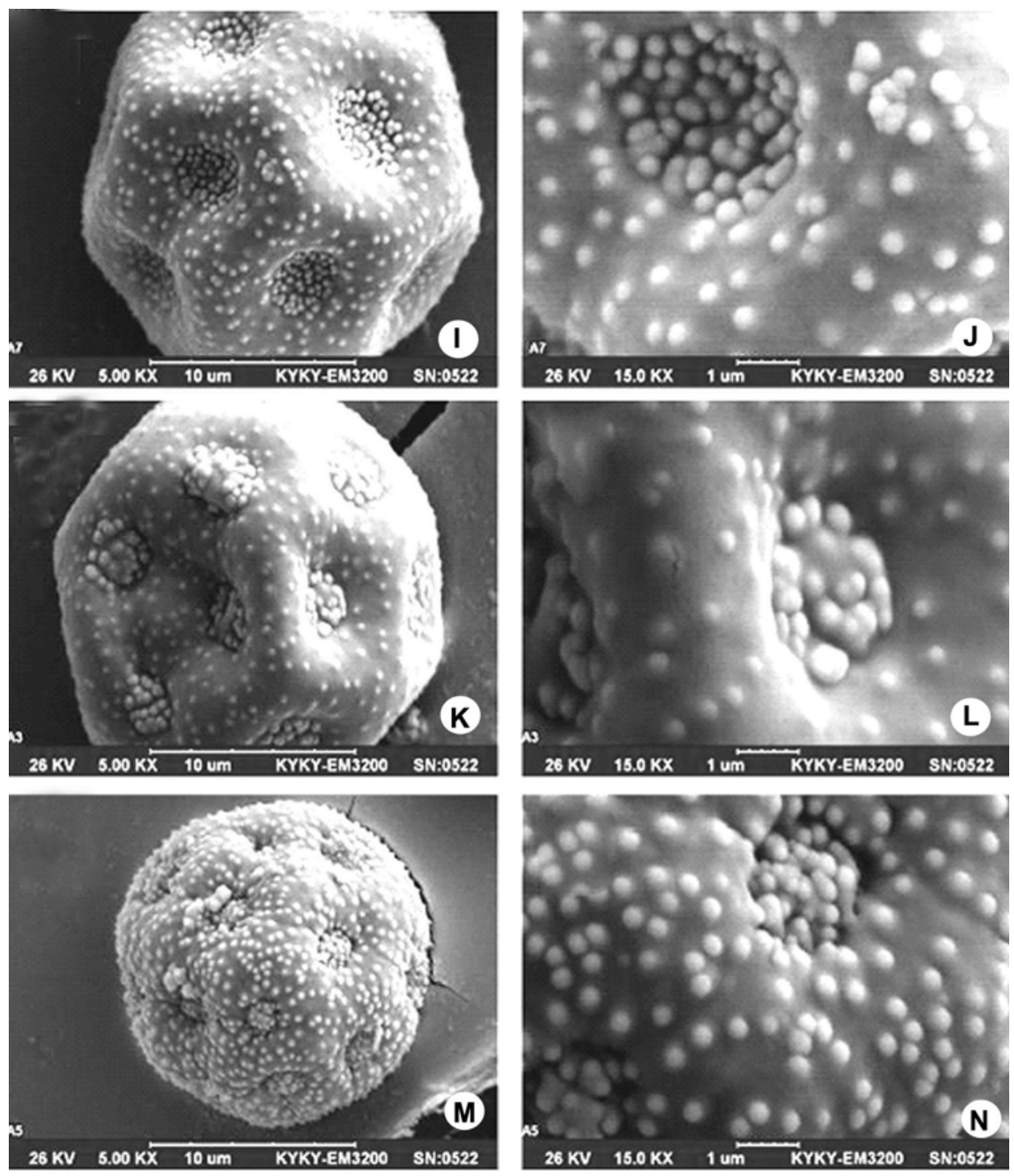

Fig. 2. Micrograph of pollen grain in Anabasis (Amaranthaceae). I-J. Faveat tectum at the proximal face in $A$. calcarea pollen with faveat ornamentation of exine. K-L. Faweat tectum at the proximal face in $A$. aphylla pollen with faveat ornamentation of exine. M-N. Faweat tectum at the proximal face in $A$. hausskanchtii pollen with faveat ornamentation of exine. Scale bars: I, K \& M = $10 \mu \mathrm{m}$; J, L \& $N=1$ $\mu \mathrm{m}$.

\section{Discussion}

The basic palynomorphological characters of Anabasis in all studied species are the occurrence of spherical shape and peripolyporate pollens. The importance of pore number and C/D ratio in the Chenopodium L. species was emphasised by Andrews \& Swanson (1967) and Uotila (1997). The present study does not show any correlation between pore number and pollen size. 
The present study confirms the findings of Pinar \& Inceoglu (1999) and Hamdi et al. (2009) that the pollen morphology of the Salsola L. and Chenopodium species in general shows uniform type characteristics by pollen micromorphology. Pollen grains in the Anabasis can be grouped into two groups as found in Amaranthaceae by Tsukada (1967).

Pollen morphological characters of the Anabasis species are closely related to Salsola, Suaeda Forssk. Ex Scop., Chenopodium, Halocharis Moq. , Sarcobatus Nees , Traganum Delile of Amaranthaceae, as well as to the pollen morphology type found in Portulacaceae, Phytolacaceae and Caryophyllaceae (Tsukada, 1967; Uotila, 1974; Skvarla \& Nowicke, 1976), Youngjae \& Lee, 1995; Borsch, 1998); Pinar \& Inceoglu, 1999; Hamdi et al., 2009 and Nikolaevna Toderich et al., 2010). There is variation in distance between the centers of the adjacent pores and corresponding pore number (Mc Andrews \& Swanson, 1967). Nikolaevna Toderich (2010) noted the correlation between length of the polar and equatorial axes and size of the flower in Salsola. This study suggests that there are significant differences in pollen size, tubercles on surface exine, distance between the centers of the adjacent pores and pore numbers on surface exine within Anabasis species. The results of this study show that pollen micromorphology can be used in delimiting species of this genus.

Based on pollen morphological characters following key is provided in indentifying seven species in Anabasis from Iran

\section{Key to Iranian Anabasis species based on pollen characters}

1. Pore diameter (inner) of holes on the exine less than $3 \mu \mathrm{m}$

- Pore diameter (inner) of holes on the exine more than $3 \mu \mathrm{m}$

2. Pore diameter (outer) of holes on the exine less than $4 \mu \mathrm{m}$

- Pores diameter (outer) of holes on the exine more than $4 \mu \mathrm{m}$

3. Pore height less than $0.3 \mu \mathrm{m}$

- $\quad$ Pore height more than $0.3 \mu \mathrm{m}$

4. Number of conical tubercle on holes 80-83

- $\quad$ Number of conical tubercle on holes 32-35

5. Pore diameter inner less than $0.5 \mu \mathrm{m}$

- Pore diameter inner more than $0.5 \mu \mathrm{m}$

6. Number of conical tubercle on holes 46-49

- $\quad$ Number of conical tubercle on holes 80-85

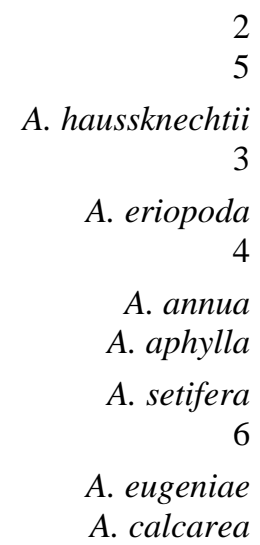

2

5

3

A. annua

A. aphylla

6

A. calcarea

\section{References}

Akhani, H., Edwards, G. and Roalson, E.H. 2007. Diversification of the old world Salsoleae s.l. (Chenopodiaceae): molecular phylogenetic analysis of nuclear and chloroplast data sets and a revised classification. Int. J. Plant. Sci. 168:931-956.

APG III (Angiosperm Phylogeny Group). 2009. An update of the Angiosperm Phylogeny Group classification for the orders and families of flowering plants: APG III. Bot. J. Linn. Soc. 161: 105-121.

Assadi, M., 2001. Chenopodiaceae. In Assadi, M. (ed.), Flora of Iran. Research Institute of Forests and Rangelands Press, Teheran, 38: 27-65.

Borsch, T. 1998. Pollen types in the Amaranthaceae. Morphology and evolutionary significance. - Grana 37: 129-142.

Davies, H.A., 1999. General preparation of material and staining of sections. Methods Mol. Biol., 117:1-11.

Freitag H. 1997. Salsola L. (Chenopodiaceae). In: Rechinger, K.H. (Ed.) Flora Iranica, Akademische Druck und Verlagsanstalt, Graz. 172:154-255. 
Hamdi, S.M.M., Malekloo, M., Assadi, M. and Nejadsatari, T. 2009. Pollen micromorphological studies of the genus Chenopodium L. (Chenopodiaceae) in Iran. Asian. J. of Plant Sciences. 8(2): 129-137.

Kadereit, G., Borsch, T., Weising, K. and Freitag, H. 2003. Phylogeny of Amaranthaceae and Chenopodiaceae and the evolution of C4 photosynthesis. Int. J. Plant Sci. 164:959-986.

Ku“hn, U., Bittrich, V., Carolin, R., Freitag, H., Hedge, I.C., Uotila, P. and Wilson, P.G. 1993. Chenopodiaceae. In: Kubitzki, K., Rohwer, J.G., Bittrich, V. (Eds) The families and genera of vascular plants. Springer, Berlin, 2: 253-281.

Mc Andrews, J.H. and Swanson, A.R. 1967. The pore number of periporate pollen with special reference to Chenopodium. Rev. Paleobot. Palynol. 3: 105-117.

Moore, P.D., Webb J.A. and Collinson M.E. 1991. Pollen Analysis. Well Scientific Publication Oxford.

Nikolaevna Toderich, K., Viktorovna Shuyskaya E., Ozturk M., Juylova A. and Gismatulina L. 2010. Pollen morphology of some Asiatic species of Genus Salsola (Chenopodiaceae) and its taxonomic; Pak. J. Bot., Special Issue (S.I. Ali Festschrift) 42: 155-174.

Pinar, N.M. and Inceoglu O. 1999. Pollen morphology of Turkish Chenopodium L. (Chenopodiaceae). Turk J. Bot. 23(3): 181-189.

Punt, W., Blackmore, S., Nilsson, S. and Le Thomas, A. 1994. Glossary of Pollen and Spore Terminology. Utrech: LPP Foundation.

Pyankov, V.I., Artyusheva E.G., Edwards G.E., Black C.C. and Soltis P.S. 2001. Phylogenetic analysis of tribe Salsoleae (Chenopodiaceae) based on ribosomal ITS sequences: implications for the evolution of photosynthesis types. Am. J. Bot. 88:1189-1198.

Tsukada, M. 1967. Chenopod-amaranth pollen: Electron microscopic identification. Science, 157: 80-82.

Uotila, P. 1974. Pollen morphology in European species of Chenopodium section Chenopodium with special reference to C. album and C. suecicum. Ann. Bot. Fennici 11: 44-58.

Uotila, P. 1997. Chenopodium. In: Flora Iranica No. 172, Rechinger, K.H. (Ed.) Akademische Drucku, Verlagsanstalt, Graz, pp: 24-59.

Youngjae, C. and S. Lee. 1995. Pollen morphology of some Korean Chenopodiaceae. Korean J. Plant Taxon. 25(4): 255-276. 